\title{
A Comparative Study on the Seasonal Variation in Alginic Acid Extracted from two Brown Seaweed Species P. pavonica Linnaeus and P. tetrastromatica Hauck
}

\author{
Rashida Qari' ${ }^{*}$, Fozia Khan Siyal ${ }^{2}$ and Abdul Razak Mahar ${ }^{2}$ \\ ${ }^{1}$ Department of Maritime Studies, Bahria University, Karachi Campus, Pakistan \\ ${ }^{2}$ Department of Botany, Shah Abdul Latif University, Khairpur, Pakistan \\ *Corresponding Author: Rashida Qari, Department of Maritime Studies, Bahria University, Karachi. Pakistan.
}

Received: September 04, 2019; Published: October 18, 2019

DOI: $10.31080 /$ ASMI.2019.02.0406

\begin{abstract}
The Phaeophycean or brown algae are large group of filamentous and macroscopic plants have practical applications as a source of structurally and functionally unique polysaccharides, alginic acid. Alginic acid is a linear Block-copolymer consists of two uronic acids, D-mannuronic acid and L-guluronic acid linked with 1 - 4 glycosidic linkage bonds. The alginic acid extraction is based on conversion of mixed salts of alginic acids in to the soluble form. Brown seaweeds are found in great abundance at Karachi coast. The present studies deal with survey of two attached brown alga of the same genus (P. pavonia and P. tetrastomatica) along the four different sites of Karachi coast for its alginic acid and other biochemical constituents. The concentration of alginic acid in $P$. pavonia was found to vary from 6.16-44.35 \% and in P. tetrastomatica vary from 6.28 - 42.86 \% in all four study shores (Hawks Bay, Buleji, Paradise Point and Manora) samples. The results showed high concentration of alginic acid found in winter and low in summer. Mostly the physical properties relative density and viscosity of alginic acids of both species were also high in winter. Moisture contents of the sample range from 5.89 to $13.9 \%$. Ash content varied from 23.54 to $41.35 \%$ and carbohydrates from 28.51 to $46.98 \%$. Biomass availability of this alga ranged from 570 to $1150 \mathrm{gm}^{-2}$ varying temporally along the coast.
\end{abstract}

Keywords: Polysaccharides; Alginic Acid; Extraction; Phaeophyta And Karachi Coast

\section{Introduction}

Polysaccharides are complex carbohydrates, composed of ten to up to several thousand monosaccharides arrange in chains. The most common monosaccharide that appears as parts of polysaccharides are glucose, fructose, galactose and mannose. Polysaccharides forming on the one hand structural element of cell wall whereas on the other hand storage forms of carbohydrates in plants [1]. Polysaccharides have high molecular weight and are not easily soluble in water.

Seaweeds are used in many maritime countries as a source of food, industrial applications and as fertilizers. Marine algae or seaweeds are particularly interesting with regard to the range of diversity of polysaccharides structure. Polysaccharide products on account of their physical properties have been used in a variety of practical applications [2].

The alginic acid is the most abundant water soluble gelling polysaccharides of brown seaweeds especially the members of Phaeophycean. Alginic acid contents are generally varied from 40 $\%$ to $80 \%$ of dry weight defatted algal biomass; depend on the environmental factors $[3,4]$. The structurally brown algal thallus depends primarily on alginates (alginic acid and its salts), and its ability to form gels and viscous solutions contributes to the flexibility of algae. Among the macromolecules of the Sargassum, Padina Cytosmear and other brown algae, alginic acid was identified as the most important constituent [5]

Alginic acid is widely demanded in food, pharmaceutical, textile, paint and paper industries. Properties of alginic acid utilized in these products are thickening, stabilizing, gel forming and film forming. Seaweeds play a small but very important role in the direct economy of many countries. Commercially alginate is principally extracted from species of Microcystis, Laminaria, Ascophyllan and Sargassum. The world market for alginates, excluding China, was over 22,000 tonnes per annum and worth almost US\$45M in 1990.

Biochemical constituents of seaweeds such as carbohydrate, ash, protein, amino acid and lipids etc. have been extensively investigated in various parts of the world, to mention a few: Dictyota 
ceylinica from Sunder ban, India [6], Laminaria, Sargassum and Focus sp. From Saint Martin, s Island of Bangladesh [7], Laminaria sp., Undrain pinnatifida and Hizkiya fusiform from China, Japan and Korea [8], Sargassum horneri from Japan sea of Toyama prefecture, Japan [9].

A number of researchers from different coast of the world have conducted the studies for biomass of seaweed [10-13]. Recently Engelen., et al. [14] studied the biomass of Sargassum polycation around the Island of Curacao, Netherlands Antilles. Recently Khan., et al. [15] studied alginic acid yield, biochemical composition and biomass in eleven brown seaweed species of cape Monze shore, Karachi. Khan and Qari [16] studied variation in Biomass, biochemical composition and alginic acid content in two brown seaweeds Spongiosum variable Kutz and Stoechospermum marginatum Agardh. Khan and Qari [17] studied on seasonal; variation in water soluble polysaccharides alginic acid extracted from Sargassum boveanum J. Agardh (Phaeophyta, Sargassaceae) along the different shore of Karachi coast, Pakistan.

In Pakistan large numbers of seaweeds are found and many of which occur in great abundance but still are not utilized as a source of alginic acid. Although amongst Phaeophycean most of the species are abundantly found all year round on the coast of Karachi [18 -23]. The present study is initiated to assess the two Padina species ( $P$. pavonica and P. tetrastromatica) potential as a source of alginic acid that could be used for future exploitation.

\section{Material and Methods}

Seaweeds were collected on monthly intervals for the period of whole one year from four different shores of Karachi coast i.e., Hawks Bay, Buleji, Paradise Point and Manora. The sampling method of Chapman [24] was followed for estimating the seaweed biomass. A quadrate of one-meter square was used for sampling. Each month ten quadrates (ten feet apart) from low tidal mark to high tidal mark were randomly sampled in the intertidal zone. All the seaweeds were hand-picked and brought to the laboratory than washed with seawater followed by fresh water to remove adhering impurities and epiphytes. For further estimation seaweed samples were dried at $70^{\circ} \mathrm{C}$ for 24 hours till constant weight and were ground in fine homogenized powder.

The extraction of alginic acid method is used described by Haug [25]. The determination of purity and the physical properties i.e., relative density and viscosity of alginic acid the methods of Whyte., et al. [26] and Whyte [27] were followed. Schematic process of alginic acid extraction in brown seaweed is presented in figure 1. Moisture and ash contents were estimated by standard method of
A.O.A.C. [28]. The carbohydrate was estimated by the phenol-sulfuric acid method reported by Dubois., et al [29].

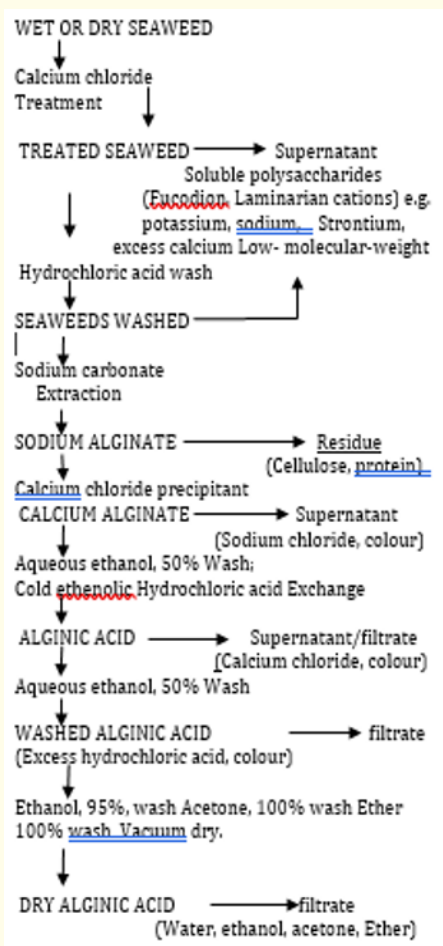

Figure 1: Schematic diagram of alginic acid extraction process.

\section{Results and Discussion}

The data about seasonal variation in water soluble polysaccharide alginic acid of two brown species P. pavonica and P. tetrastromatica reveals high variability in the content of alginic acid and their physical properties in between species, collection time and sampling shores. Figure 2 showed that the highest concentrations of alginic acid were found during the winter season (NovemberFebruary) while the small percentage of alginic acid was found in summer season (May- August). The highest yield of alginic acid was obtained from P. tetrastomatica as compared with P. pavonica (Figure 3). It is also noted that the highest alginic acid content was found in the samples of Buleji shore as compared to other shores (Figure, 4).

The concentration of alginic acid in P. pavonia were found to vary from 2.35.14.64 \% at all four study shores (Hawks Bay, Buleji, Paradise Point and Manora) of Karachi coast with the mean value of $10.53 \pm 2.20 \%$ at Hawks Bay, $9.02 \pm 2.71 \%$ at Buleji, $10.92 \pm$ $2.05 \%$ at Paradise Point and $11.42 \pm 1.84 \%$ at Manora (Figure 5). At Hawks Bay the alginic acid content was found high in November (14.64\%) and low in July (6.16\%) and at Buleji the content 


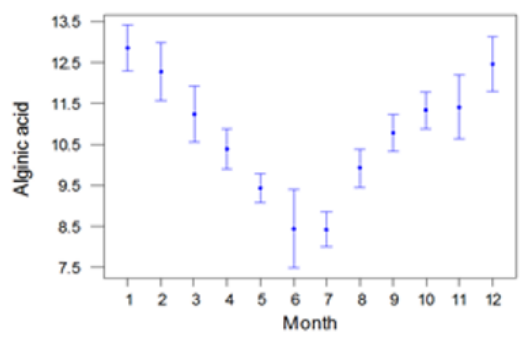

Figure 2: Monthly variation in alginic acid content (\% dry wt) of P. pavonia and P. tetrastomatica.

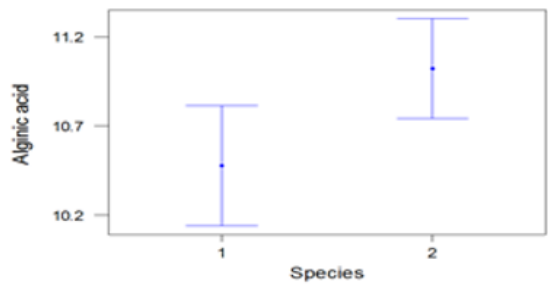

Figure 3: Variation in alginic acid content (\% dry wt) of P. pavonia and P. tetrastomatica

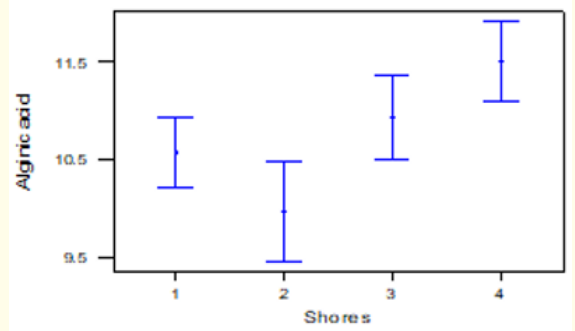

Figure 4: Variation in alginic acid content (\% dry wt) of P. pavonia and P. tetrastomatica at different shores of Karachi coast.

was found high in September (12.37\%) and low in June (2.35 \%) (Figure 5). At Paradise Point alginic acid content was found high in March (14.16 \%) and low in July (8.16 \%) and at Manora shore it was high in December (14.61\%) and low in July (8.34 \%) (Figure $5)$.

The concentrations of alginic acids in P. tetrastomatica were found in a range of $7.34-16.61 \%$ at all four study shores with the mean value of $10.61 \pm 1.29 \%$ at Hawks Bay, $10.92 \pm 1.99 \%$ at Buleji, $10.94 \pm 2.26 \%$ at Paradise Point, $11.61 \pm 2.20 \%$ at Manora and $14.07 \pm 0.253 \%$ at Cape Monze (Figure 6). The alginic acid

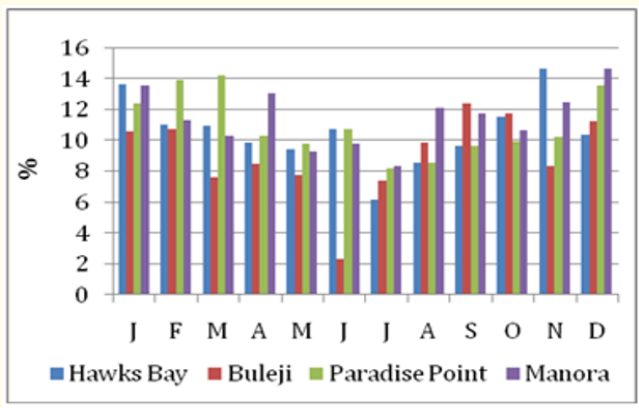

Figure 5: Seasonal variation in alginic acid content of $P$. pavonia.

content in P. tetrastomatica was found high in a period of February, March and December (12.11 - $12.18 \%$ ) and low in June (8.54 \%) at Hawks Bay where as it was high in October (13.89\%) and low in June (7.34 \%) at Buleji (Figure 6). At Paradise Point the alginic acid content was high in February (16.61\%) and low in June (8.54 \%) and at Manora shore it was high in January (15.49\%) and low in a period of April-June (9.45-9.76 \%) (Figure 6).

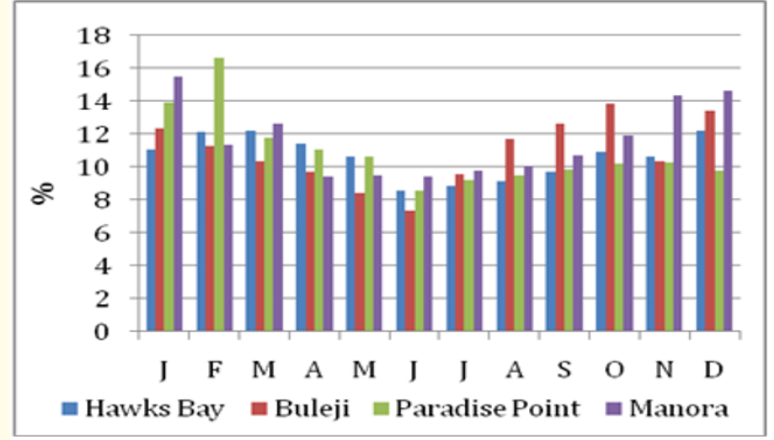

Figure 6: Seasonal variation in alginic acid content of $P$. tetrastomatica.

In P. pavonia Hawks Bay shore sample the relative density of alginic acids was high in the month of December $\left(0.935 \mathrm{~g} / \mathrm{cm}^{3}\right)$ and low in the month of March $\left(0.757 \mathrm{~g} / \mathrm{cm}^{3}\right)$ whereas in Buleji sample it was high in the month of March $\left(0.99 \mathrm{~g} / \mathrm{cm}^{3}\right)$ and low in January $\left(0.69 \mathrm{~g} / \mathrm{cm}^{3}\right)$ (Figure 7). At Paradise Point shore sample the relative density was high in May $\left(0.94 \mathrm{~g} / \mathrm{cm}^{3}\right)$ and low in February $(0.74 \mathrm{~g} /$ $\mathrm{cm}^{3}$ ) whereas at Manora sample the high value of relative density was found in July $\left(0.97 \mathrm{~g} / \mathrm{cm}^{3}\right)$ and low in January and April $(0.79$ $\mathrm{g} / \mathrm{cm}^{3}$ ) (Figure 7).

In P. tetrastomatica Hawks Bay sample the physical property of alginic acid, relative density was found high in the month of January $\left(0.997 \mathrm{~g} / \mathrm{cm}^{3}\right)$ and low in the month of April $\left(0.843 \mathrm{~g} / \mathrm{cm}^{3}\right)$ whereas in Buleji sample it was high in the month of May $(0.935 \mathrm{~g} /$ 


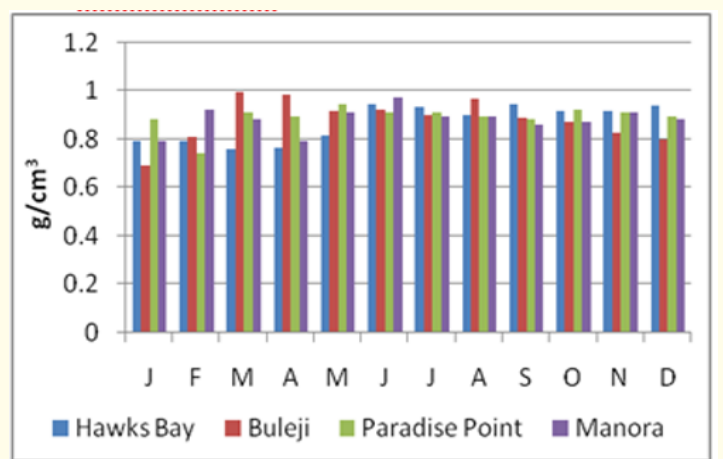

Figure 7: Seasonal variation in gel density of P. pavonia.

$\left.\mathrm{cm}^{3}\right)$ and June $\left(0.934 \mathrm{~g} / \mathrm{cm}^{3}\right)$ while low in December $\left(0.851 \mathrm{~g} / \mathrm{cm}^{3}\right)$ (Figure 8). In Paradise Point shore sample the relative density of $P$. tetrastomatica was high in April $\left(0.96 \mathrm{~g} / \mathrm{cm}^{3}\right)$ and low in January $\left(0.68 \mathrm{~g} / \mathrm{cm}^{3}\right)$ whereas in Manora sample the high value of relative density was found in May $\left(0.93 \mathrm{~g} / \mathrm{cm}^{3}\right)$ (Figure 8 ).

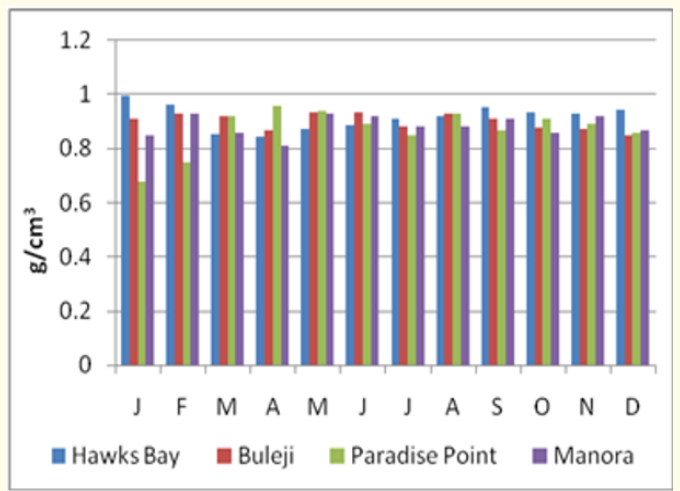

Figure 8: Seasonal variation in gel density of $P$. tetrastomatica.

In P. pavonia Hawks Bay sample the high viscosity of alginic acid was found in December (109.3 cp) and low in August (84.6cp) where as in Buleji shore sample the viscosity was high in August (99.3 cp) and low in February (71.81 cp) (Figure 9). In Paradise Point sample viscosity was high in April (101.36 cp) and low in February $(73.9 \mathrm{cp})$ and in Manora sample the value of viscosity was high in the month of February ( $91.4 \mathrm{cp}$ ) and low in January and March (78.4 cp) (Figure 9).

In Hawks Bay sample of P. tetrastomatica the high viscosity of alginic acid was found in March (104.5 cp) and December (103.4 cp) and low in August (82.5 cp) where in Buleji sample viscosity was high in December (98.3 cp) and low in November (77.9cp) (Figure 10). In Paradise Point sample viscosity was high in July (104.9cp) and low in January (67.4cp) and in Manora sample the value of viscosity was high in the month of July ( $99.5 \mathrm{cp})$ and low in January and August (71.6 cp) (Figure 10).

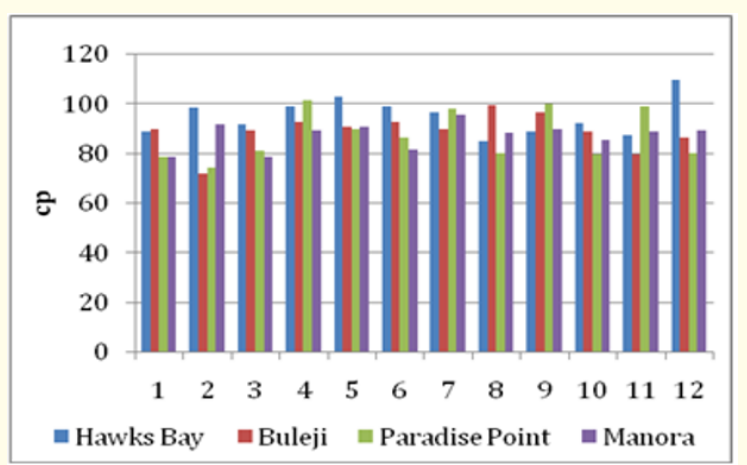

Figure 9: Seasonal variation in viscosity of $P$. pavonia.

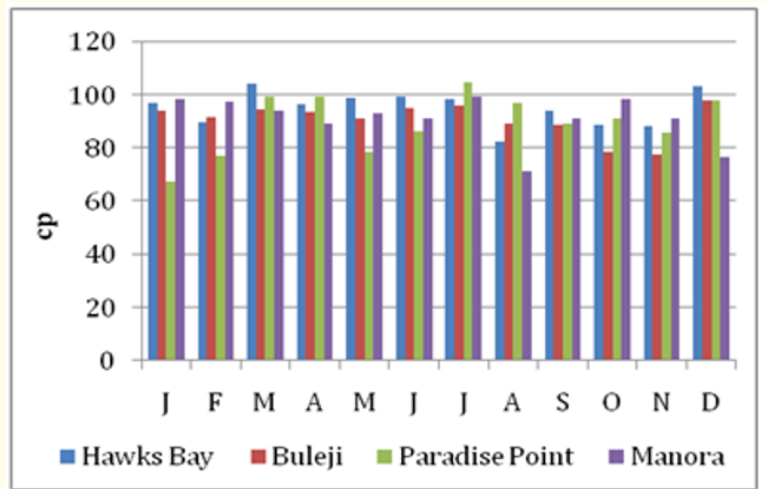

Figure 10: Seasonal variation in viscosity of $P$.tetrastomatica.

Carbohydrate concentrations of brown seaweed P. pavonia were vary from $24.51-44.35 \%$ with the mean value of $29.96 \pm 2.87 \%$ in Hawks Bay samples, $31.46 \pm 3.34 \%$ in Buleji samples, $31.47 \pm 2.16$ $\%$ in Paradise Point samples and $34.77 \pm 5.2 \%$ in Manora samples. The carbohydrate concentrations in Hawks Bay sample were high in January (35.16 \%) and low in June (24.51 \%) and in Buleji sample high concentrations were found in January (37.64\%) and low in March (24.92 \%) (Figure 11). In Paradise Point sample the values of carbohydrate found high in January (36.13\%) and low in June (29.59\%) where as in Manora samples high concentrations was found in February (44.35 \%) and low in July (28.46 \%) (Figure 11).

Carbohydrate concentrations in P. tetrastomatica were vary from $23.16-42.86 \%$ with the mean value of $36.07 \pm 2.19 \%$ in Hawks Bay samples, $32.42 \pm 5.69 \%$ in Buleji samples, $31.43 \pm$ $2.09 \%$ in Paradise Point samples, $39.75 \pm 1.62 \%$ in Manora shore 
samples. The carbohydrate concentrations in Hawks Bay samples were high in January (39.43\%) and low in September (33.69\%) and in Buleji samples high concentrations were found in January $(39.28 \%)$ and low in July (23.16 \%) (Figure 12). At Paradise Point samples the values of carbohydrate were high in December $(34.63$ $\%$ ) and low in May (28.42 \%) whereas in Manora samples high carbohydrate concentrations were found in February (42.86 \%) and low in May (37.16 \%) (Figure 12).

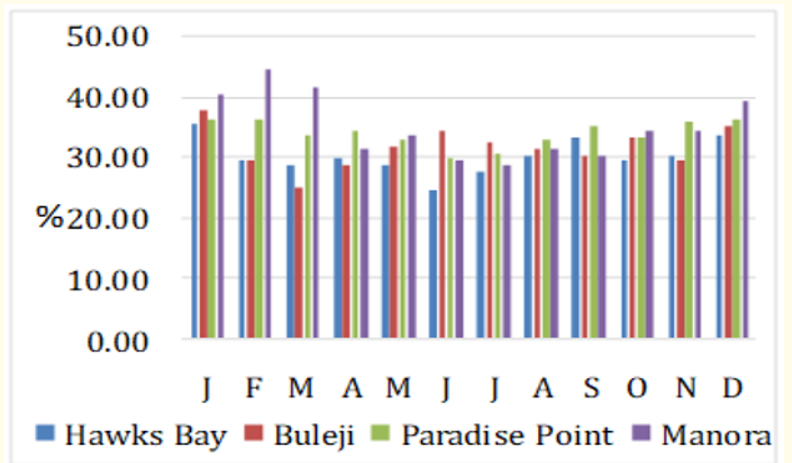

Figure 11: Seasonal variation in carbohydrate content of P. pavonia.

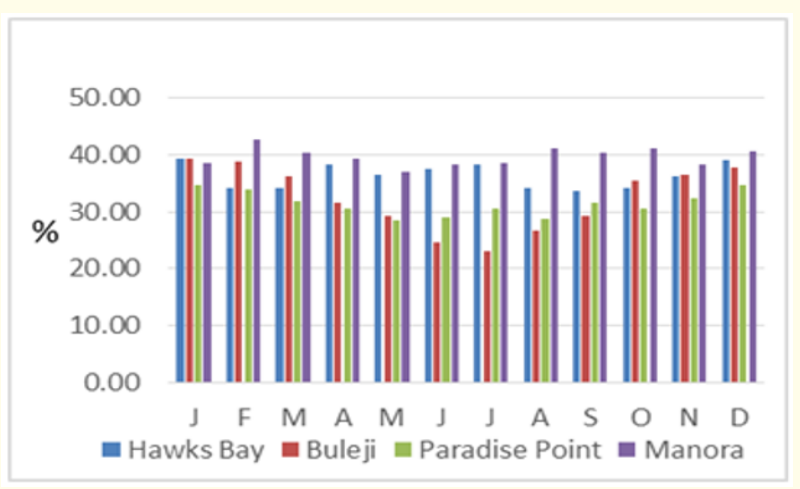

Figure 12: Seasonal variation in carbohydrate content of $P$. tetrastomatica.

Ash concentrations in P. pavonia were vary from 24.35 - 37.46 $\%$ with the mean values of $32.65 \pm 3.72 \%$ in Hawks Bay sample, $28.04 \pm 2.38 \%$ in Buleji sample, $33.10 \pm 2.31 \%$ in Paradise Point, $31.04 \pm 3.56 \%$ in Manora samples. In Hawks Bay shore samples ash concentrations were high in March (37.46 \%) and low in $\mathrm{Au}-$ gust (26.34\%), and in Buleji samples high in January (32.78 \%) and low in June (24.35\%) (Figure 13). In Paradise Point samples ash concentrations were high in January (37.29 \%) and low in July (29.34\%) whereas in Manora samples high ash concentrations were found in September and June (36.0\%) and low in November (25.6\%) (Figure 13).

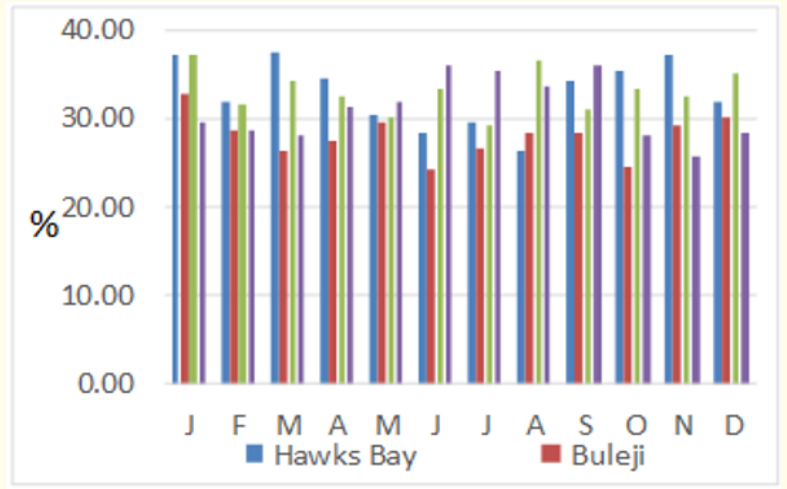

Figure 13: Seasonal variation in ash content of $P$. pavonia.

Ash concentrations in P. tetrastomatica were vary from 21.47 $37.59 \%$ with the mean values of $30.76 \pm 3.12 \%$ in Hawks Bay samples, $27.95 \pm 3.21 \%$ in Buleji samples, $31.23 \pm 1.73 \%$ in Paradise Point samples and $29.56 \pm 1.93 \%$ in Manora samples. In samples of Hawks Bay shore ash concentrations were high in August (37.59 $\%$ ) and low in June (27.36 \%) and in Buleji samples it was high in November (31.94 \%) and low in October (23.26 \%) (Figure 14). In Paradise Point samples ash concentrations were high in September (34.29\%) and low in period of June and October (29.19\%) where as in Manora samples high ash values were found in period of January and May (32.31 \%) and low in March (26.84 \%) (Figure 14).

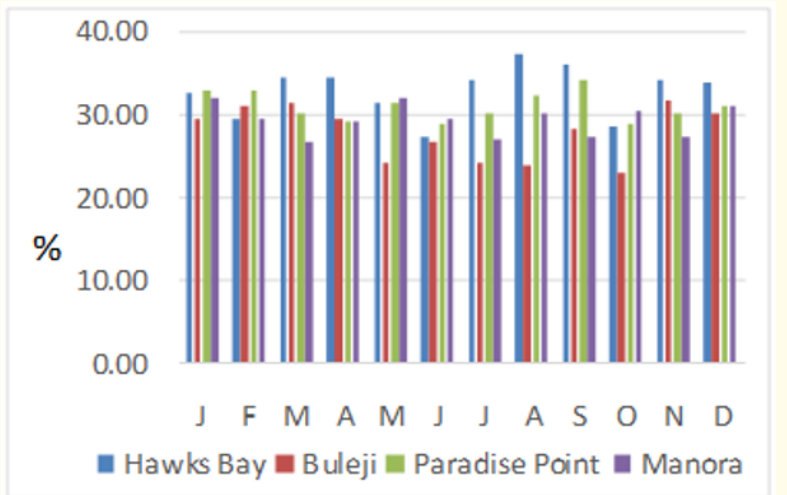

Figure 14: Seasonal variation in ash content of $P$. tetrastomatica.

The concentrations of moisture in P. pavonia were vary from $6.16-13.6 \%$ with the mean values of $7.46 \pm 1.03 \%$ in Hawks Bay samples, $7.80 \pm 0.88 \%$ in Buleji samples, $10.77 \pm 1.33 \%$ in Paradise Point samples and $11.04 \pm 1.31 \%$ in Manora samples. In 
Hawks Bay samples, moisture of seaweeds were found high in December (9.53\%) and low in March (6.16 \%) and in Buleji samples high moisture was found in February $(9.31 \%)$ and low in November (6.24 \%) (Figure 15). In Paradise Point samples moisture was high in February (12.49\%) and low in July (8.34\%) where as in Manora samples high moisture values were found in January (13.6 $\%)$ and low in May (9.4\%) (Figure 15).

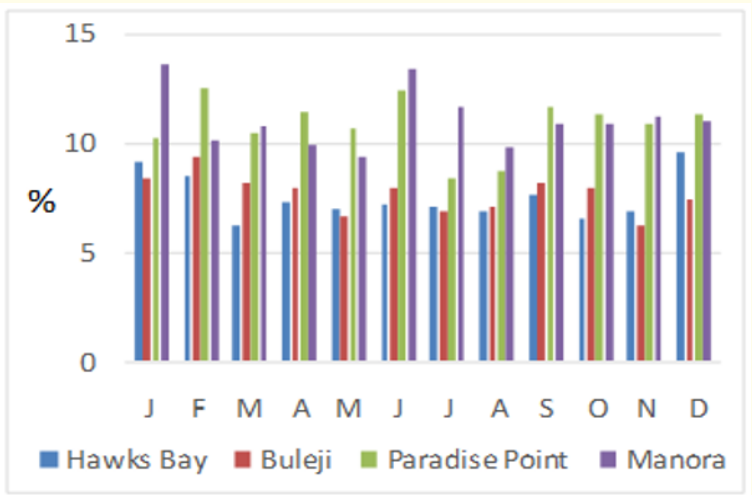

Figure 15: Seasonal variation in Moisture content of $P$. pavonia.

In P. tetrastomatica concentrations of moisture were vary from $4.85-12.37 \%$ with the mean values of $7.46 \pm 1.13 \%$ in Hawks Bay samples, $6.50 \pm 1.21 \%$ in Buleji samples, $10.87 \pm 1.04 \%$ at Paradise Point and $8.67 \pm 1.51 \%$ in Manora samples. In Hawks Bay samples moisture concentrations were found high in February (9.44 \%) and low in June (6.33\%) and in Buleji samples it was high in November (9.79\%) and low in September (4.85 \%) (Figure 16). In Paradise Point samples moisture was high in October (12.37\%) and low in May (9.36 \%) whereas in Manora samples high moisture values were found in February (11.2\%) and low in May (6.25 \%) (Figure 16).

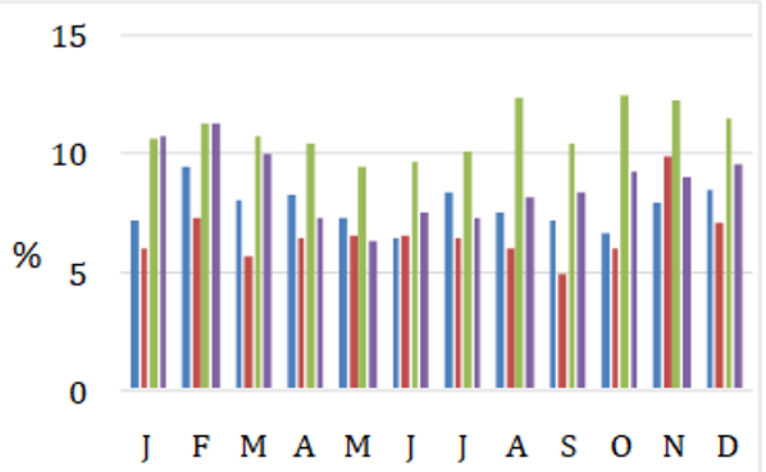

- Hawks Bay Buleji $\square$ Paradise Point $\mathbf{M}$ Manora

Figure 16: Seasonal variation in moisture content of $P$. tetrastomatica.
Biomass of Padina pavonia was range from $135-480 \mathrm{gm}^{-2}$ with the mean values of $331.25 \pm 69.51 \mathrm{gm}^{-2}$ at Hawks Bay, $288.3 \pm 93.88$ $\mathrm{gm}^{-2}$ at Buleji, $304.58 \pm 64.08 \mathrm{gm}^{-2}$ at Paradise Point and $283.75 \pm$ $99.72 \mathrm{gm}^{-2}$ at Manora. At Hawks Bay biomass of seaweeds was found high in January $\left(420 \mathrm{gm}^{-2}\right)$ and low in September $\left(195 \mathrm{gm}^{-2}\right.$ ) and at Buleji high biomass was found in February $\left(480 \mathrm{gm}^{-2}\right)$ and low in April (180 $\mathrm{gm}^{-2}$ ) (Figure17). At Paradise Point biomass was high in November $\left(410 \mathrm{gm}^{-2}\right)$ and low in July $\left(175 \mathrm{gm}^{-2}\right)$ whereas at Manora high biomass was found in January and February $\left(410 \mathrm{gm}^{-2}\right.$ ) and low in August (135 $\mathrm{gm}^{-2}$ ) (Figure 17).

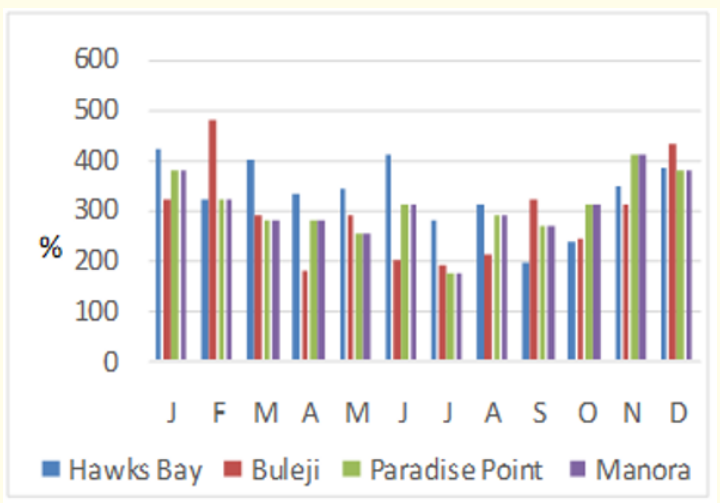

Figure 17: Seasonal variation in biomass of $P$. pavonia.

Biomass of $P$. tetrastomatica range from $145-410 \mathrm{gm}^{-2}$ with the mean values of $276.25 \pm 64 \mathrm{gm}^{-2}$ at Hawks Bay, $249.16 \pm 94.84 \mathrm{gm}^{-2}$ at Buleji, $250.41 \pm 69.49 \mathrm{gm}^{-2}$ at Paradise Point, and $279.58 \pm 86.27$ $\mathrm{gm}^{-2}$ at Manora. At Hawks Bay biomass of seaweeds was found high in December (390 $\left.\mathrm{gm}^{-2}\right)$ and low in August (185 gm-2) and at Buleji high biomass was found in December $\left(410 \mathrm{gm}^{-2}\right)$ and low in April (120 $\mathrm{gm}^{-2}$ ) (Figure 18). At Paradise Point biomass was high in November $\left(380 \mathrm{gm}^{-2}\right)$ and low in May $\left(175 \mathrm{gm}^{-2}\right)$ where as at Manora it was high in December (410 $\left.\mathrm{gm}^{-2}\right)$ and low in August (145 $\mathrm{gm}^{-2}$ ) (Figure 18).

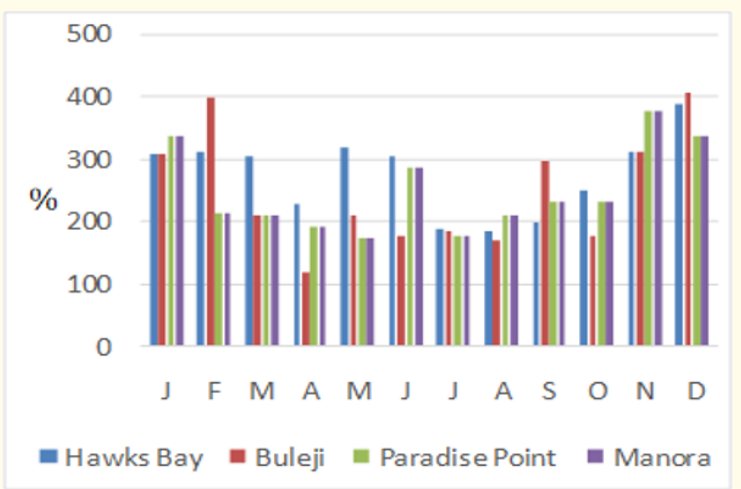

Figure 18: Seasonal variation in biomass of $P$. tetrastomatica. 
The completely randomized design with nested treatments analysis of variance (ANOVA) model was used to test the significant differences of alginic acid and its physical properties in seaweed between month shores and species (Table 1). The results showed that there were high significant variations found between month and sites for alginic acid $(\mathrm{F}=6.61$ and $\mathrm{F}=3.78$ respectively). Significant variations were also found in between species for relative density $(\mathrm{F}=1.81)$ and between month, sites and species for viscosity ( $\mathrm{F}=1.67, \mathrm{~F}=4.52, \mathrm{~F}=2.78$ respectively). There was significant correlations were also found in between month, sites and species for carbohydrates $(\mathrm{F}=3.36, \mathrm{~F}=12.08$ and $\mathrm{F}=12.9$ respectively) and moisture ( $\mathrm{F}=1.99, \mathrm{~F}=54.88$ and $\mathrm{F}=11.15$ respectively). Whereas for ash most significant variations was found only in between sites $(\mathrm{F}=15.05)$. There was significant variation were also found in between month and species for biomass $(F=10.37$ and $\mathrm{F}=11.40$ respectively).

\begin{tabular}{|c|c|c|c|c|}
\hline \multirow{2}{*}{$\begin{array}{l}\text { Alginic } \\
\text { Source } \\
\end{array}$} & \multicolumn{2}{|c|}{ Acid } & \multirow[b]{2}{*}{$\mathbf{F}$} & \multirow[b]{2}{*}{$\mathbf{P}$} \\
\hline & DF & Adj MS & & \\
\hline Month & 11 & 17.570 & $6.61^{* * *}$ & 0.000 \\
\hline Species & 1 & 7.200 & 2.71 & 0.104 \\
\hline Shores & 3 & 10.049 & $3.78^{*}$ & 0.014 \\
\hline Error & 80 & 2.659 & & \\
\hline Total & 95 & & & \\
\hline \multicolumn{5}{|l|}{ Density } \\
\hline Source & DF & Adj MS & $\mathbf{F}$ & $\mathbf{P}$ \\
\hline Month & 11 & 0.006 & $1.81^{*}$ & 0.066 \\
\hline Species & 1 & 0.006 & 1.78 & 0.186 \\
\hline Shores & 3 & 0.001 & 0.230 & 0.875 \\
\hline Error & 80 & 0.003 & & \\
\hline Total & 95 & & & \\
\hline \multicolumn{5}{|c|}{ Viscosity } \\
\hline Source & DF & Adj MS & $\mathbf{F}$ & $\mathbf{P}$ \\
\hline Month & 11 & 91.500 & $1.67^{*}$ & 0.095 \\
\hline Species & 1 & 152.060 & $2.78^{*}$ & 0.099 \\
\hline Shores & 3 & 247.260 & $4.52^{* *}$ & 0.006 \\
\hline Error & 80 & 54.700 & & \\
\hline Total & 95 & & & \\
\hline \multicolumn{5}{|c|}{ Carbohydrate } \\
\hline Source & DF & Adj MS & $\mathbf{F}$ & $\mathbf{P}$ \\
\hline Month & 11 & 38.520 & $3.36^{* *}$ & 0.001 \\
\hline Species & 1 & 148.190 & $12.92^{* *}$ & 0.001 \\
\hline Shores & 3 & 138.610 & $12.08^{* * *}$ & 0.000 \\
\hline Error & 80 & 11.470 & & \\
\hline Total & 95 & & & \\
\hline Ash & & & & \\
\hline
\end{tabular}

\begin{tabular}{|l|c|c|c|c|}
\hline Source & DF & Adj MS & F & P \\
\hline Month & 11 & 10.290 & 1.33 & 0.224 \\
\hline Species & 1 & 16.319 & 2.11 & 0.150 \\
\hline Shores & 3 & 116.532 & $15.05^{* * *}$ & 0.000 \\
\hline Error & 80 & 7.742 & & \\
\hline Total & 95 & & & \\
\hline \multicolumn{2}{|c|}{ Moisture } & & & \\
\hline Source & DF & Adj MS & F & P \\
\hline Month & 11 & 2.819 & $1.99^{*}$ & 0.041 \\
\hline Species & 1 & 15.836 & $11.15^{* *}$ & 0.001 \\
\hline Shores & 3 & 77.930 & $54.88^{* * *}$ & 0.000 \\
\hline Error & 80 & 1.420 & & \\
\hline Total & 95 & & & \\
\hline Biomass & & & & \\
\hline Source & DF & Adj MS & F & P \\
\hline Month & 11 & 31730 & $10.37^{* * *}$ & 0.000 \\
\hline Species & 1 & 34884 & $11.4^{* *}$ & 0.001 \\
\hline Shores & 3 & 5325 & 1.74 & 0.165 \\
\hline Error & 80 & 3061 & & \\
\hline Total & 95 & & & \\
\hline
\end{tabular}

Table 1: Analysis of variance (ANOVA) for alginic acid, physical properties and biochemical constituents in seaweed (P. pavonia and P. tetrastomatica) from Karachi coast.

$\left\{{ }^{*}=\right.$ Significant at $\mathrm{P}<0.05,{ }^{* *}=$ Significant at $\mathrm{P}<0.01$, $* * *=$ Significant at $\mathrm{P}<0.001\}$.

There was significant correlations were found in between alginic acid of different shores samples such as Buleji and Manora samples of $P$. pavonia $\left(\mathrm{r}^{2}=0.515\right)$ and Hawks Bay and Paradise Point samples of $P$. tetrastomatica $\left(\mathrm{r}^{2}=0.627\right)$. Significant correlation were also found in between different parameters of both species (P. pavonia and P. tetrastomatica) for example in between alginic acid $\left(r^{2}=0.927\right)$, relative density $\left(r^{2}=0.613\right)$, carbohydrate $\left(r^{2}=0.896\right)$, ash $\left(r^{2}=0.675\right)$ and biomass $\left(r^{2}=0.921\right)$. A significant correlations were also found in between different parameters of same species for example in P. pavonia alginic acid and carbohydrate samples $\left(r^{2}=0.886\right)$, alginic acid and ash $\left(r^{2}=0.539\right)$, alginic acid and biomass $\left(r^{2}=0.789\right)$, relative density and viscosity $\left(r^{2}=\right.$ $0.564)$, ash and carbohydrate $\left(r^{2}=0.573\right)$, carbohydrate and biomass $\left(\mathrm{r}^{2}=0.778\right)$ and moisture and biomass $\left(\mathrm{r}^{2}=0.572\right)$ and in $P$. tetrastomatica samples in between alginic acid and carbohydrate $\left(r^{2}=0.946\right)$, ash and carbohydrate $\left(r^{2}=0.542\right)$, moisture and carbohydrate $\left(r^{2}=0.742\right)$, biomass and carbohydrate $\left(r^{2}=0.716\right)$ and biomass and moisture $\left(r^{2}=0.603\right)$. 
A wide variation was found in alginic acid concentration extracted from both (P. pavonia and P. tetrastomatica) species collected in different localities in different seasons. P. tetrastomatica February sample of Paradise Point (16.61\%) have high alginic acid concentrations while the lowest value of alginic acid concentrations were recorded in P. pavonia June sample of Buleji (2.35 \%). It was also observed that the alginic acid yield was high in both species of Padina when attained its maximum biomass [30]. The relative density was also high during winter period in both species. The variation were found in alginic acid, and carbohydrate concentrations at studied shore in different seasons due to the environmental factors like temperature, $\mathrm{pH}$, light, salinity and dissolved oxygen $[19,31,32]$. In present work the colour of alginic acid was dark brown i.e., it was as commercial standard [33].

Marked changes in the biochemical constituents and biomass were apparent among the both species of brown seaweeds at all studied shores. The results of carbohydrate were recorded in the present study have much resemblance with the results of Chakraborty and Santra [6] for the Dictyota dichotoma from Sunder ban India; Hossain., et al. [9] for the species of Sargassum from Toyama Prefecture, Japan and Arvizu., et al. [34] for Eisenia arbora from Baja California Sur, Mexico. The marine plants especially seaweeds have 80 - 90\% water and consider as biologically important for metabolism because it participates in the chemical reactions of metabolism as a source of hydrogen ion [9].

In present study the high carbohydrate values were found in winter season and low in summer season like the alginic acid and biomass. Significance individual differences were observed in the biochemical composition (carbohydrate, ash and moisture) and biomass with change of season and environmental factors [31,35]. Environmental factors (light, temperature, $\mathrm{pH}$, salinity and dissolved oxygen) may change the nutritional status of seaweeds $[9,36]$. Light intensity also affect the concentrations of carbohydrate i.e., the intensity of the light is high then the rate of photosynthesis will increase but, the rate of photosynthesis will only increase to an extent after intensity of light reaches a certain point photosynthesis rate will stay still and due to this way affecting the carbohydrates synthesis. Dissolved oxygen levels in sea water also affect the biochemical composition as it is high in the winter season and related to photosynthetic activity of marine plants and more production of plants [31]. Qari and Siddiqui [37] studied the hydrographic condition in sea water and reported that dissolved oxygen in seawater was high in winter or northeast monsoon period (November-February) and low in summer or southwest monsoon season (mid May- mid September). The high dissolved oxygen in northeast monsoon period can be related to photosynthetic activity and more production of plants.
It is concluded from the present results it is clear that the seaweed species P. pavonia and P. tetrastomatica are edible and can be used for human food because both studied species of seaweed have considerable amount of Alginic acid and biochemical constituents (carbohydrate, ash and moisture). Considering these facts, the present data contributes baseline information for future exploitation of seaweeds as a source of alginic acid and carbohydrate. Results of the study also indicate that winter season (November-February) is the best time to harvest the brown seaweed species especially $P . p a-$ vonia and $P$. tetrastomatica that produce the high viscosity alginic acid and carbohydrate for the industrial use.

\section{Bibliography}

1. Percival E and McDowell RH. "Chemistry and enzymology of marine algal polysaccharides". Academic Press, London (1967): 219.

2. Chapman VJ and Chapman DJ. "Seaweed and their uses". Chapman and Hall, London. New York (1980): 334

3. Zvyagintseva TN., et al. "Water-soluble polysaccharides of some far-eastern brown seaweeds. Distribution, structure, and their dependence on the developmental conditions". Journal of Experimental Marine Biology and Ecology 294 (2003): 1-13.

4. Honya M., et al. "Monthly changes in the content of fucans, their constituent sugars and sulfate in cultured Laminaria japonica". Hydrobiologia 398.399 (1999): 411-416.

5. Davis TA., et al. "Extraction, isolation and cadmium binding of alginate from Sargassum spp". Journal of Applied Phycology 16 (2004): 275-284.

6. Chakraborty S and Santra SC. "Biochemical composition of eight benthic algae collected from Sunderban". Indian Journal of Marine Sciences 37.3 (2008): 329-332.

7. Azad B., et al. "Study on biochemical composition of brown seaweeds collected from Saint Martin's Island of Bangladesh". European Journal of Scientific Research 17.1 (2007): 97-105.

8. Dawczynski C., et al. "Amino acids, fatty acids and dietary fibres in edible seaweed products". Food Chemistry 103 (2007): 891-899.

9. Hossain Z., et al. "Biochemical composition and lipid compositional properties of brown Alga Sargassum horneri. Pakistan". Journal of Biological Sciences 6.17 (2003): 1497-1500. 
10. Pacheco-Ruiz I and Zertuche-Gonzalez JA. "Brown algae (Phaeophyta) from Bahia de Los Angeles, Gulf of California, Mexico". Hydrobiologia 326.327 (1996): 169-172.

11. Hay $\mathrm{CH}$ and Villouta E. "Seasonality of the Adventive Asian Kelp Undaria pinnatifida in New Zealand". Botanica Marina 36(1993): 461-476.

12. Untawale AG and Dhargalkar VK. "Ecological studies of Ulva reticulata Forsskal in Chapora Bay (Goa)". National Institute Oceanography 19 (1986): 175-184.

13. Chock JS and Mathieson AC. "Variations of New England estuarine seaweeds Biomass”. Botanica Marina 26 (1993): 87-97.

14. Engelen AH., et al. "Effects of wave exposure and depth on biomass, density and fertility of the fucoids seaweed Sargassum polyceratium (Phaeophyta, Sargassaceae)". European Journal of Phycology 40.2 (2005): 149-158.

15. Khan F., et al. "Alginic acid yield, biochemical composition and biomass in brown seaweed species of cape Monze shore, Karachi In: Climate change impact on ecosystem". Sundaresan J., Sreekesh, S. Ramanathan, A.I. Sonnenschein, L and Boojh, R. eds. Scientific Publisher, India. (2013): 220

16. Khan AR and Qari R. "Antibacterial activities of brown seaweed Sargassum boveanum (j. ag.) against diarrhea along the coast of Karachi, Pakistan". Journal of Environmental Research and Development 6.3A (2012): 753-757.

17. Khan F and Qari R. "Seasonal; variation in water soluble polysaccharides alginic acid extracted from Sargassum boveanum J. Agardh (Phaeophyta, Sargassaceae) along the different shore of Karachi coast, Pakistan". International Journal of Biology and Biotechnology 6.4 (2009): 277-281.

18. Qari R and Khan E. "Diversity of green seaweeds along the coast of Karachi". International Journal of Marine Science 8.22(2018):176-185.

19. Qari R. "An assessment of Seaweeds Diversity and Distribution at the Beach of Nathia Gali, Karachi, Pakistan". Journal of Marine Science: Research and Development 7 (2017): 228.

20. Qari R., et al. "Phytomass Studies on Natural Bed of Seaweed at Paradise Point, Karachi Coast". International Journal of Economic and Environment Geology 5.2 (2014): 11-17.
21. Qari R and Qasim R. "Seasonal change in the standing crop of intertidal seaweeds from Manora coast, Karachi". In: Proc. Nat. Sem. Fish Policy and Planning, Majid, A., M.Y. Khan, M. Moazzam, J. Ahmed, eds. Marine Fisheries Department (1994): 279286.

22. Qari R and Qasim R. "Seasonal change in the standing crop of intertidal seaweeds from the Karachi coast". In: Proc. Marine Science of the Arabian Sea. Thompson M. F. and Tirmizi N.M., eds. American Institutes of Biological Sciences, Washington, D.C. (1988): 449-456.

23. Saifullah SM. "A preliminary survey of the standing crop of seaweeds from Karachi coast". Botanica Marina 16 (1973): 139144.

24. Chapman VJ. "Coastal vegetation". Pergaman Press, Oxford (1964).

25. Haug A. "Composition and properties of alginates". Report Norsk Institutt Seaweed Research 30 (1964): 123.

26. Whyte JNC., et al., "Seasonal variations in the Biomass, Quantity and Quality of Agar, from the Reproductive and Vegetative Stages of Gracilaria (verrrucosa type)". Botanica Marina 24.9 (1981): 493-501.

27. Whyte JN. "Extraction of alginic acid from brown seaweed" In: Experimental Phycology- A Laboratory Mannual. Lobban, C.S., Chapman, D.J. and Kremer B.P. eds. Cambridge, University Press, Cambridge. (1988): 168-183.

28. AOAC. "Official methods of analysis". 15th edition, Association Official Analytical Chemists. Arlington, Virginia. (1990): 684.

29. Dubios M., et al. "Colorimetric method for determination of sugars". Analytical Chemistry 28 (1956): 350.

30. Ragaza AR and Hurtado AQ. "Sargassum studies in Currimao, Ilocos Norte, Northern Philippines II. Seasonal variations in alginate yield and viscosity of Sargassum carpophyllum J. Agardh, Sargassum ilicifolium (Turner) C. Agardh and Sargassum siliquosum J. Agardh (Pheophyta, Sargassaceae)". Botanica Marina 42 (1999): 327-331.

31. Qari R and Siddiqui SA "Variation of hydrographic conditions in seawater from Nathia Gali of Karachi coast". Pakistan Journal of Marine Sciences 14.2 (2005a): 93-100. 
32. Qari R and Siddiqui SA. "Heavy metal levels in coastal seawater of Paradise Point, Karachi". Segmite 1 (2004): 21-25.

33. Jothisaraswathi S., et al. "Seasonal studies on alginate and its biochemical composition I: Sargassum polycystum. (Fucales), Phaeophyceae". Phycological Research 51 (2003): 240-243.

34. Arvizu DL., et al. "Chemical constituents of Eisenia arborea Areschoug from Baja California Sur, Mexico". Investigations Marinas 35.2 (2007): 63-69.

35. Manivannan K., et al. "Biochemical composition of seaweeds from Mandapam coastal regions along Southeast coast of India”. American-Eurasian Journal of Botany 1.2 (2008): 32-37.

36. Boechat IG and Giani A. "Factors affecting biochemical composition of seston in an eutrophic reservoir (Pampulha Reservoir, Belo Horizonte, MG)". Revista Brasileira de Biologia 60.1 (2000): 63-71.

37. Qari R and Siddiqui SA. "Variations of heavy metals in green seaweeds from Karachi coast of Pakistan". Pakistan Journal of Scientific and Industrial Research 48.3 (2005b): 195-201.

\section{Volume 2 Issue 11 November 2019}

(C) All rights are reserved by Rashida Qari., et al. 